\title{
Pengaruh Jenis Pelarut pada Metode Microwave Assisted Extraction (MAE) terhadap Karakteristik Ekstrak Daun Singkong (Manihot utilissima Pohl.)
}

\section{The Effect of Type of Solvent Using Microwave Assisted Extraction (MAE) Method on The Characteristics of Cassave Leaf Extract (Manihot utilissima Pohl.)}

\author{
Yustika Ayu Tri Wahyuni ${ }^{1}$, Gusti Ayu Kadek Diah Puspawati ${ }^{1 *}$, I Nengah Kencana Putra ${ }^{1}$ \\ Program Studi Teknologi Pangan, Fakultas Teknologi Pertanian, Universitas Udayana \\ Kampus Bukit Jimbaran, Badung-Bali \\ *Penulis korespondensi: Gusti Ayu Kadek Diah Puspawati, Email: diahpuspawati@unud.ac.id
}

\begin{abstract}
Cassava leaf has bioactive components, such as flavonoids and chlorophyll pigments, but the information on cassava leaf extract is still limited and needs development on the using extraction method of microwave. The type of solvent is an important factor in the success of extracting the material. This research was conducted to determine the effect of the solvent using Microwave Assisted Extraction (MAE) method on the characteristics of cassava leaf extract (Manihot utilissima Pohl.) and to find the right type of the solvent using Microwave Assisted Extraction (MAE) to produce the best cassava leaf extract. The research design used was a Completely Randomized Design with a solvent type treatment consisting of five types of solvents, namely aquades, ethanol $90 \%$, acetone $90 \%$, methanol $90 \%$, and ethyl acetate $90 \%$. The treatment was repeated three times to obtain 15 experimental units. The data obtained were analyzed by the analysis of variance and if the treatment had a significant effect to variable observed, it was continued with Duncan's Multiple Range Test. The parameters observed in this study were yield, total chlorophyll content, total flavonoids content, antioxidant activity, $\mathrm{IC}_{50}$, and $\mathrm{L}^{*}, \mathrm{a}^{*}, \mathrm{~b}^{*}$ values. The result showed that the type of solvent had a very significant effect $(\mathrm{P}<0,01)$ on yield, total chlorophyll content, total flavonoids, antioxidant activity, IC $\mathrm{C}_{50}$, and $\mathrm{L}^{*}, \mathrm{a}^{*}, \mathrm{~b}^{*}$ values. The best treatment was found in ethanol $90 \%$ which produced a yield $19.84 \%$, total flavonoids $74.90 \mathrm{mg}$ QE/g, total chlorophyll $9.98 \mathrm{mg} / \mathrm{g}$, antioxidant activity $83.67 \%$, and L*: 44.83, a*: $-9.97, \mathrm{~b}^{*}: 20.27$.
\end{abstract}

Keywords: cassava leaf, solvent type, MAE, extraction

\section{PENDAHULUAN}

Tanaman singkong (Manihot utilissima Pohl.) merupakan salah satu jenis tanaman yang termasuk dalam famili euphorbiaceae dengan genus Manihot yang penyebarannya cukup banyak di Asia, khusunya Indonesia (Sari, 2017). Daun singkong sejak dahulu dimanfaatkan sebagai obat herbal untuk mengobati luka karena memiliki komponen bioaktif yang berupa flavonoid dan saponin yang berperan sebagai antiinflamasi dan antibakteri (Anggraini, 2017). Daun singkong selain mempunyai komponen bioaktif berupa flavonoid juga memiliki pigmen klorofil yang cukup tinggi. Setiari dan Yulita (2009) melaporkan bahwa kandungan klorofil pada daun singkong sebesar 27,4467 mg/g, kedua tertinggi setelah daun pepaya. Senyawa flavonoid dan pigmen klorofil pada daun singkong juga dapat berperan sebagai antioksidan (Rohimat et al., 2014). Antioksidan adalah komponen yang dapat mencegah atau menghambat reaksi oksidasi akibat adanya reaksi berantai (Ridlo et al., 2017).

Kandungan senyawa bioaktif pada daun singkong dapat dipengaruhi oleh posisi daun. Daun pada posisi 4-7 dari pucuk merupakan posisi yang baik karena tidak terlalu muda dan juga tidak 
terlalu tua. Selain itu, senyawa bioaktif seperti flavonoid dan pigmen klorofil yang terkandung pada daun di posisi 4-7 masih tergolong tinggi (Puspitarini, 2010). Selain posisi daun, varietas dan jenis singkong juga mempengaruhi senyawa bioaktif yang ada pada daun singkong. Jenis dan varietas yang berbeda akan memberikan hasil senyawa bioaktif yang berbeda pula.

Pengambilan senyawa bioaktif pada daun singkong seperti flavonoid dan pigmen klorofil dapat dilakukan dengan cara ekstraksi. Salah satu metode ekstraksi yang digunakan dalam penelitian ini adalah Microwave Assisted Extraction (MAE). Microwave Assisted Extraction (MAE) merupakan salah satu metode ekstraksi yang memanfaatkan radiasi gelombang mikro untuk mempercepat proses ekstraksi melalui pemanasan pelarut secara cepat dan efisien (Jain, et al., 2009). Fabrowska et al. (2017) melaporkan bahwa ekstraksi MAE jauh lebih efisien pada isolasi klorofil dan karotenoid dari ganggang hijau air tawar dibandingkan dengan ekstraksi soxhlet dan Supercritical Fluid Extraction (SFE). Putranto (2018) melaporkan bahwa aktivitas antioksidan daun kenikir pada metode MAE memiliki nilai lebih tinggi dibandingkan aktivitas antioksidan dengan metode maserasi.

Keberhasilan proses ekstraksi dengan metode MAE dipengaruhi oleh beberapa faktor, seperti waktu ekstraksi, jenis pelarut, rasio bahan:pelarut, daya microwave, dan suhu microwave. Jenis pelarut merupakan faktor yang paling utama dalam proses ekstraksi MAE dibandingkan dengan faktor lainnya (Rifai, 2018). Berdasarkan prinsip like dissolve like, suatu pelarut akan cenderung melarutkan senyawa yang mempunyai tingkat kepolaran yang sama. Putri et al. (2012) melaporkan bahwa pelarut alkohol dan aseton mampu menghasilkan jumlah klorofil dalam ekstrak daun suji yang lebih tinggi dibandingkan pelarut air. Pigmen klorofil selain terekstrak dengan baik pada pelarut alkohol dan aseton juga dapat terekstrak pada pelarut metanol, khususnya klorofil pada daun pepaya (Aisy, 2018). Sementara itu, pelarut etil asetat mampu menegekstrak senyawa flavonoid dengan baik pada Spirulina plantesis (Firdiyani et al., 2015). Penelitian lain juga menunjukkan bahwa pelarut etanol dapat mengekstrak senyawa flavonoid tertinggi pada daun sawo duren (Sulistyo, 2019). Penelitian ini bertujuan untuk menentukan pengaruh jenis pelarut pada metode MAE terhadap karakteristik ekstrak daun singkong (Manihot utilissima Pohl.) dan mendapatkan jenis pelarut yang tepat pada metode MAE untuk menghasilkan karakteristik ekstrak daun singkong terbaik.

\section{METODE PENELITIAN}

\section{Tempat dan Waktu Penelitian}

Penelitian ini dilaksanakan di Laboratorium Analisis Pangan, Laboratorium Pengolahan Pangan, dan Laboratorium Teknik Pasca Panen Fakultas Teknologi Pertanian, Universitas Udayana. Penelitian ini dilakukan pada bulan November 2020 sampai bulan Januari 2021.

\section{Bahan dan Alat}

Bahan-bahan yang digunakan dalam penelitian ini, yaitu daun singkong (Manihot utilissima) yang didapatkan di daerah Renon, Denpasar-Bali. Daun singkong yang digunakan adalah daun yang masih segar, utuh, dan terletak pada posisi 4-6 dari pucuk tanaman. Jenis tanaman 
singkong yang digunakan adalah jenis singkong putih dengan tangkai merah. Selain itu digunakan aquades, etanol PA 90\% (Merck), aseton PA 90\% (Merck), metanol PA 90\% (Merck), etil asetat PA 90\% (Merck), $\quad \mathrm{AlCl}_{3} .6 \mathrm{H}_{2} \mathrm{O} \quad($ A127 Phyto Technology Laboratories), reagen kuersetin (Zigma), dan DPPH (2,2-diphenyl-1-picrylHydrazyl) (Zigma).

Alat-alat yang digunakan dalam penelitian ini, yaitu microwave oven (Samsung), oven (Blue M), Spektrofotometer Uv-Vis (Biochrom), kertas saring Whattman No. 1, timbangan analitik (Shimadzu ATY224), rotary vacuum evaporator, labu evaporasi (Iwaki) tabung reaksi (Pyrex), pipet mikro (Eppendorf), tip, corong, pipet volume $1 \mathrm{ml}$ (Pyrex), pipet volume $5 \mathrm{ml}$ (Assistent), pipet tetes, vortex (Thermolyne Type 37600 Mixer), gelas beaker (Iwaki), gelas ukur (Iwaki), labu Erlenmeyer (Iwaki), botol kaca gelap, ayakan 60 mesh, dan blender.

\section{Rancangan Penelitian}

Rancangan yang digunakan dalam penelitian ini adalah Rancangan Acak Lengkap (RAL) dengan perlakuan jenis pelarut yang terdiri dari 5 jenis pelarut, yaitu $\mathrm{A}=$ Pelarut Air/Aquades, $\mathrm{B}=$ Pelarut Etanol 90\%, C = Pelarut Aseton 90\%, D = Pelarut Metanol 90\%, dan E = Pelarut Etil Asetat 90\%. Perlakuan diulang sebanyak 3 kali sehingga didapatkan 15 unit percobaan. Data yang diperoleh kemudian dianalisis dengan sidik ragam dan jika perlakuan berpengaruh dilanjutkan dengan uji Duncan's Multiple Range Test (DMRT). Keseluruhan data dianalisis menggunakan SPSS dengan selang kepercayaan $95 \%$.

\section{Pelaksanaan Penelitian}

Pelaksanaan penelitian ini melalui beberapa tahap, yaitu pembuatan bubuk daun singkong dan ekstraksi bubuk daun singkong.

\section{Pembuatan Bubuk Daun Singkong}

Daun singkong sebanyak $2000 \mathrm{~g}$ dibersihkan terlebih dahulu dengan dicuci menggunakan air mengalir kemudian ditiriskan sampai kering. Selanjutnya dipotong kecil-kecil $( \pm 2 \mathrm{~cm})$ dengan tujuan untuk mempercepat proses pengeringan. Daun singkong yang sudah dipotong-potong selanjutnya dikeringkan pada oven (suhu $50^{\circ} \mathrm{C}$ selama 4 jam). Daun singkong kering kemudian dihancurkan dengan cara diblender sampai halus dan diayak dengan menggunakan ayakan 60 mesh sehingga didapatkan bubuk daun singkong. Selanjutnya, bubuk daun singkong disimpan dalam plastik ziplock agar tidak cepat rusak.

\section{Ekstraksi Bubuk Daun Singkong dengan MAE}

Proses ekstraksi daun singkong mengacu pada penelitian Putranto (2018) yang dimodifikasi. Proses diawali dengan bubuk daun singkong ditimbang sebanyak $10 \mathrm{~g}$ dengan menggunakan timbangan analitik, kemudian dimasukkan kedalam labu erlenmeyer. Selanjutnya, ditambahkan jenis pelarut sesuai dengan perlakuan, yaitu aquades, etanol $90 \%$, aseton $90 \%$, metanol 90\%, dan etil asetat 90\% dengan perbandingan bahan dan pelarut 1:25. Proses ekstraksi menggunakan microwave oven selama 8 menit dengan daya 450 watt. Setelah proses ekstraksi berakhir, dilanjutkan dengan proses penyaringan dengan menggunakan kertas saring Whattman No. 1. Filtrat yang sudah didapatkan, dipekatkan dengan rotary vacuum evaporator sampai pelarut sudah tidak ada lagi yang menguap dan ekstrak mengental. Ekstrak kasar yang sudah 
didapatkan akan dianalisis berdasarkan parameter yang diamati.

\section{Parameter yang Diamati}

Parameter yang diamati pada penelitian ini, yaitu rendemen ekstrak daun singkong (Dewatisari et al., 2017), total flavonoid menggunakan metode $\mathrm{AlCl}_{3}$ (Chang and Wen, 2002), total klorofil menggunakan metode spektrofotometri (Maligan, 2015), aktivitas antioksidan dan $\mathrm{IC}_{50}$ menggunakan metode DPPH (Khan et al., 2012), pengukuran warna menggunakan L*, a*, b* (Sinaga, 2019).

\section{HASIL DAN PEMBAHASAN}

\section{Rendemen Ekstrak Daun Singkong}

Hasil sidik ragam menunjukkan bahwa jenis pelarut berpengaruh sangat nyata $(\mathrm{P}<0,01)$ terhadap rendemen ekstrak daun singkong. Hasil analisis rendemen ekstrak daun singkong dapat dilihat pada Gambar 3. Rendemen ekstrak daun singkong dalam penelitian ini berkisar antara $9,35 \%-19,84 \%$.

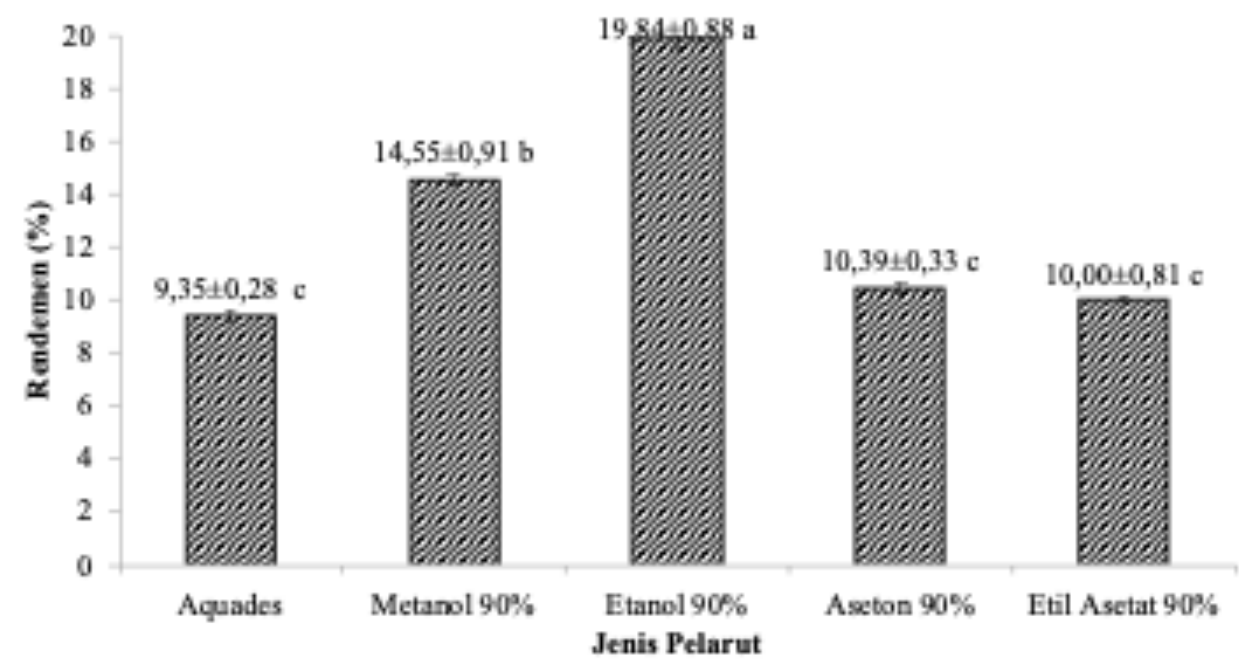

Gambar 3. Nilai rata-rata rendemen ekstrak daun singkong. Notasi yang sama menunjukkan perlakuan tidak berbeda nyata $(\mathrm{P}>0,05)$

Berdasarkan Gambar 3 dapat dilihat bahwa rendemen tertinggi terdapat pada pelarut etanol $90 \%$ yaitu 19,84\% sedangkan rendemen terendah terdapat pada pelarut aquades yaitu 9,35\%. Suatu senyawa akan larut pada pelarut yang memiliki tingkat kepolaran yang relatif sama. Kepolaran suatu pelarut dapat dilihat dari konstanta dielektriknya. Pelarut polar memiliki konstanta dielektrik yang besar sedangkan pelarut non-polar memiliki konstanta dielektrik yang kecil. Semakin besar atau tinggi nilai konstanta dielektriknya, maka semakin polar pelarut tersebut. Pelarut aquades, etanol, aseton, metanol, dan etil asetat masing-masing memiliki konstanta dielektrik sebesar 80,40, 24,3, 33,62, 20,70, dan 6,02 (Khotimah et al., 2017).

Rendemen ekstrak daun singkong dengan pelarut etanol yang tinggi menunjukkan bahwa pelarut etanol mampu mengekstrak senyawa pada daun singkong dengan lebih baik. Jika dilihat dari konstanta dielektriknya, pelarut metanol lebih polar dibandingkan pelarut etanol, akan tetapi 
pelarut etanol mampu mengekstrak senyawa dengan lebih baik karena tingkat kepolaran senyawa aktif pada ekstrak daun singkong relatif sama dengan tingkat kepolaran etanol. Hal ini juga diperkuat oleh penelitian Kemit (2016) yang melaporkan bahwa ekstraksi dengan pelarut etanol menghasilkan rendemen ekstrak daun alpukat yang lebih tinggi (27,84\%) dibandingkan pelarut air. Pelarut etanol merupakan salah satu jenis pelarut yang sering digunakan dalam proses ekstraksi karena mampu melarutkan senyawa yang bersifat polar hingga kurang polar (Yasa et al., 2019). Rendemen ekstrak daun singkong dengan metode MAE pada penelitian ini lebih tinggi dibandingkan rendemen ekstrak daun singkong dengan metode maserasi. Hal ini dibuktikan dari penelitian Sekali (2020) bahwa rendemen ekstrak daun singkong dengan metode maserasi berkisar antara 4,36\% 8,08\%. Salah satu kelebihan ekstraksi dengan metode MAE yaitu mampu menghasilkan rendemen yang lebih tinggi (Magdalena, 2015).

\section{Total Flavonoid Ekstrak Daun Singkong}

Hasil sidik ragam menunjukkan bahwa jenis pelarut berpengaruh sangat nyata $(\mathrm{P}<0,01)$ terhadap total flavonoid ekstrak daun singkong. Hasil analisis total flavonoid ekstrak daun singkong dapat dilihat pada Gambar 4. Rata-rata total flavonoid ekstrak daun singkong dalam penelitian ini berkisar antara 29,56 mg QE/g $74,90 \mathrm{mg} \mathrm{QE} / \mathrm{g}$.

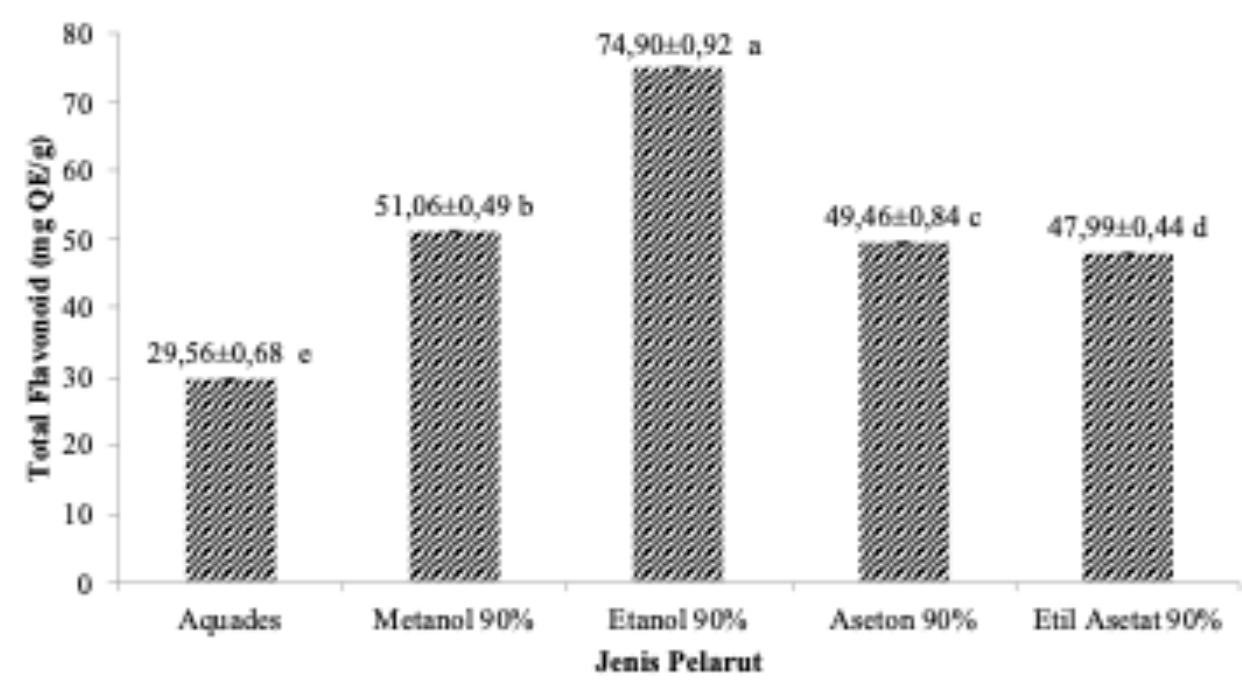

Gambar 4. Nilai rata-rata total flavonoid ekstrak daun singkong. Notasi yang sama menunjukkan perlakuan tidak berbeda nyata $(\mathbf{p}>0,05)$

Berdasarkan Gambar 4 dapat dilihat bahwa rata-rata total flavonoid tertinggi terdapat pada pelarut etanol 90\% yaitu sebesar 74,90 mg QE/g sedangkan rata-rata total flavonoid terendah terdapat pada pelarut aquades yaitu $29,56 \mathrm{mg}$ QE/g. Berdasarkan prinsip like dissolve like, suatu pelarut akan melarutkan senyawa yang memiliki tingkat kepolaran yang sama. Senyawa flavonoid tergolong senyawa yang bersifat polar karena terdapat gugus hidroksil yang terikat dengan gula (Harborne, 1987). Tingginya total flavonoid pada ekstrak daun singkong dengan menggunakan pelarut etanol menunjukkan bahwa tingkat kepolaran senyawa flavonoid pada ekstrak daun 
singkong relatif sama atau menyerupai tingkat kepolaran pelarut etanol sehingga daun singkong yang diekstrak dengan pelarut etanol mampu menghasilkan total flavonoid tertinggi. Hal ini diperkuat oleh hasil penelitian Kemit (2016) yang melaporkan bahwa pelarut etanol menghasilkan total flavonoid tertinggi yaitu $64,12 \mathrm{mg}$ QE/g pada ekstrak daun alpukat dibandingkan pelarut aquades, aseton, dan metanol.

Total flavonoid ekstrak daun singkong dengan metode MAE pada penelitian ini memiliki nilai yang lebih tinggi dibandingkan total flavonoid ekstrak daun singkong dengan pelarut etanol 70\% sebesar 49,87 mg/g pada metode maserasi (Azizah, 2020). Hal ini disebabkan karena adanya radiasi gelombang mikro pada bahan yang menyebabkan terjadinya gesekan antar molekul dipol sehingga menghasilkan panas. Panas yang dihasilkan akan menguapkan air dari sel bahan sehingga tekanan pada dinding sel bahan meningkat dan menyebabkan sel membengkak kemudian pecah. Pecahnya sel bahan tersebut menyebabkan senyawa target seperti flavonoid dapat terekstraksi secara sempurna sehingga total flavonoid yang dihasilkan lebih tinggi.

\section{Total Klorofil Ekstrak Daun Singkong}

Hasil sidik ragam menunjukkan bahwa jenis pelarut berpengaruh sangat nyata $(\mathrm{P}<0,01)$ terhadap total klorofil ekstrak daun singkong. Hasil analisis total klorofil ekstrak daun singkong dapat dilihat pada Gambar 5. Rata-rata total klorofil ekstrak daun singkong dalam penelitian ini berkisar antara $0,42 \mathrm{mg} / \mathrm{g}-9,98 \mathrm{mg} / \mathrm{g}$.

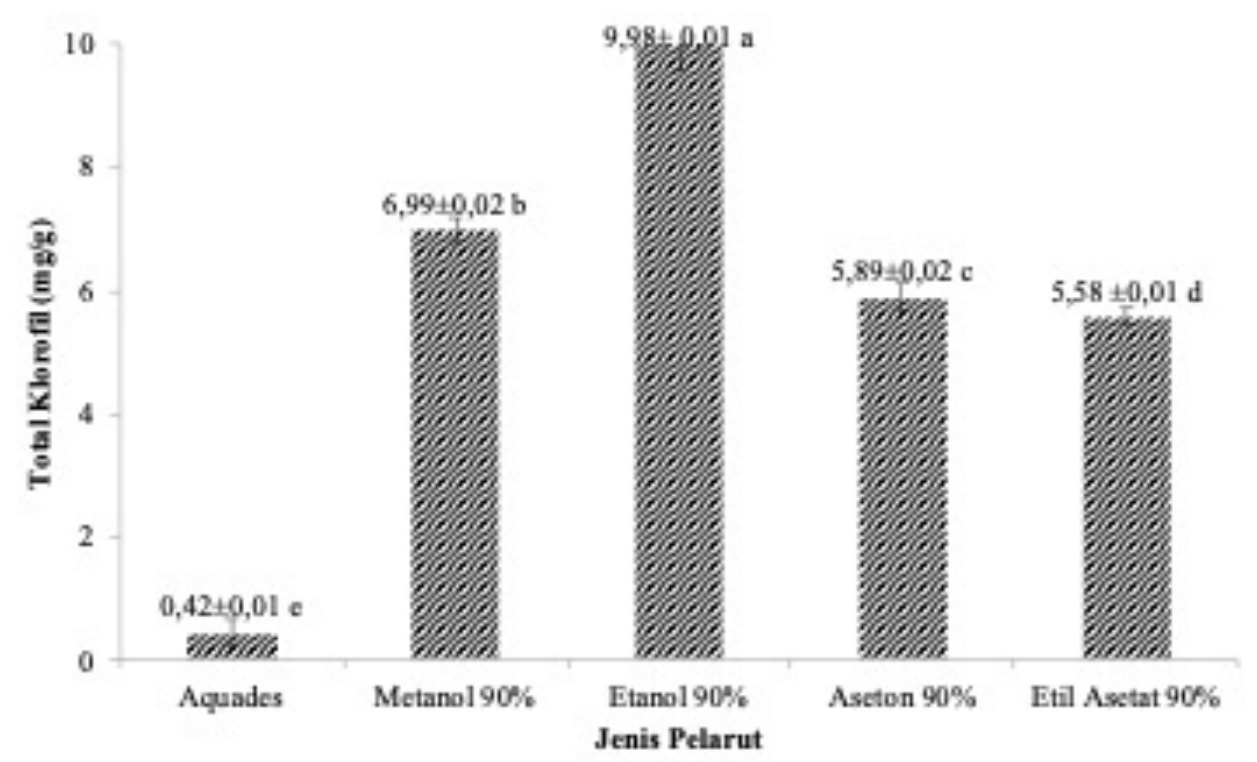

\section{Gambar 5. Nilai rata-rata total klorofil ekstrak daun singkong. Notasi yang sama menunjukkan perlakuan tidak berbeda nyata $(\mathrm{P}>\mathbf{0 , 0 5})$}

Berdasarkan sifat kimianya, klorofil tidak larut dalam air tetapi larut dalam pelarut organik yang lebih polar, seperti etanol dan aseton (Ai dan Yunia, 2011). Gambar 5 menunjukkan bahwa nilai total klorofil ekstrak daun singkong tertinggi terdapat pada pelarut etanol $90 \%$ yaitu sebesar 9,98 $\mathrm{mg} / \mathrm{g}$ sedangkan nilai total klorofil terendah terdapat pada pelarut aquades yaitu sebesar 0,42 
$\mathrm{mg} / \mathrm{g}$. Hasil penelitian ini menunjukkan bahwa klorofil memang larut dalam pelarut organik, seperti etanol, metanol, aseton, dan etil asetat. Selain karena klorofil larut dalam pelarut organik, tingginya total klorofil pada ekstrak daun singkong dengan pelarut etanol 90\% menunjukkan bahwa tingkat kepolaran pelarut etanol menyerupai tingkat kepolaran senyawa klorofil sehingga etanol mampu menghasilkan total klorofil tertinggi. Hal ini juga didukung oleh hasil penelitian Novitasari dan Robiatul (2018) yang melaporkan bahwa total klorofil pada daun mangkokan dengan pelarut etanol $85 \%$ lebih tinggi dibandingkan aseton $85 \%$ yaitu sebesar $0,043 \mathrm{mg} / \mathrm{g}$. Nilai total klorofil ekstrak daun singkong dengan metode MAE pada penelitian ini lebih tinggi dibandingkan nilai total klorofil ekstrak daun singkong dengan metode maserasi. Hal ini dibuktikan dari penelitian Arrohmah (2007) bahwa total klorofil ekstrak daun singkong pada metode maserasi sebesar 0,016 $\mathrm{mg} / \mathrm{g}$.

\section{Aktivitas Antioksidan dan IC $_{50}$ Ekstrak Daun Singkong}

Hasil sidik ragam menunjukkan bahwa jenis pelarut berpengaruh sangat nyata $(\mathrm{P}<0,01)$ terhadap aktivitas antioksidan ekstrak daun singkong. Hubungan jenis pelarut terhadap aktivitas antioksidan dapat dilihat pada Gambar 6. Nilai rata-rata aktivitas antioksidan ekstrak daun singkong dalam penelitian ini berkisar antara $68,84 \%-83,67 \%$.

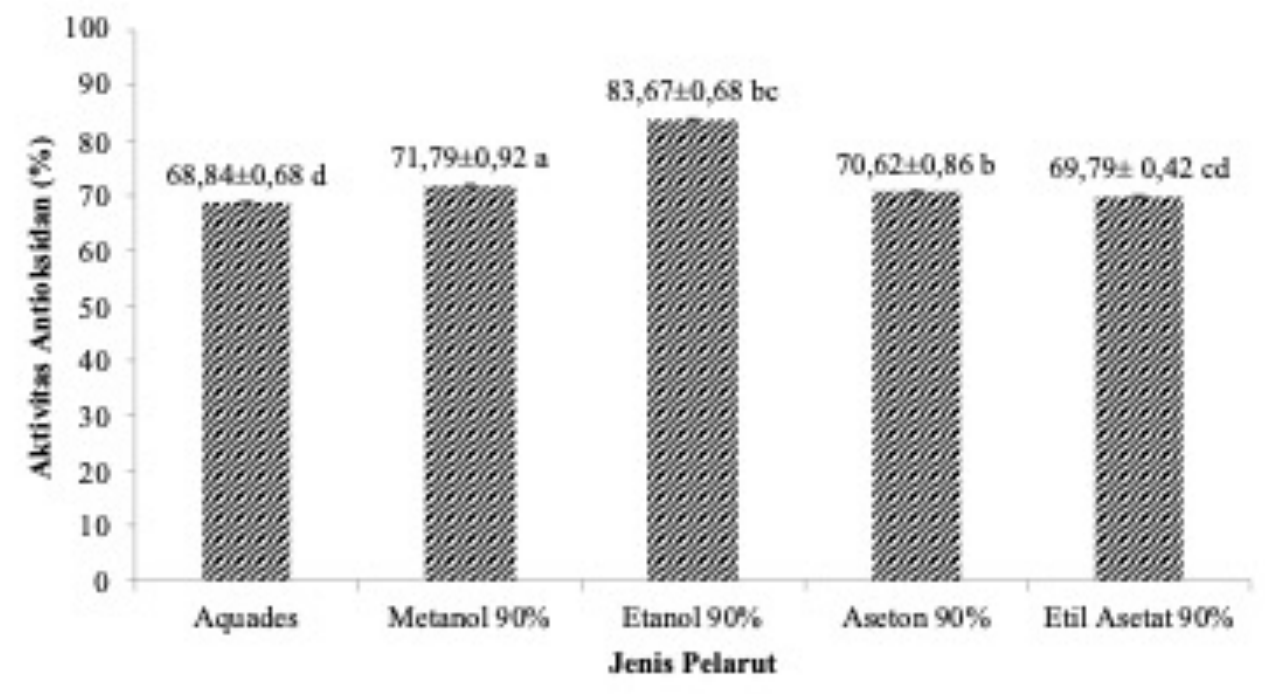

Gambar 6. Nilai rata-rata aktivitas antioksidan ekstrak daun singkong. Notasi yang sama menunjukkan perlakuan tidak berbeda nyata $(\mathrm{P}>0,05)$

Berdasarkan Gambar 6 dapat dilihat bahwa aktivitas antioksidan ekstrak daun singkong tertinggi terdapat pada pelarut etanol $90 \%$ yaitu $83,67 \%$ sedangkan aktivitas antioksidan terendah terdapat pada pelarut aquades yaitu $68,84 \%$. Aktivitas antioksidan ekstrak daun singkong yang tinggi pada pelarut etanol disebabkan karena konstanta dielektrik dari etanol sebesar 24,30 yang artinya tingkat kepolaran etanol mampu menyerupai tingkat kepolaran dari ekstrak daun singkong sehingga daun singkong yang diekstrak dengan pelarut etanol menghasilkan persentase 
aktivitas antioksidan tertinggi. Selain itu, pelarut etanol mampu melarutkan senyawa yang bersifat polar hingga kurang polar sehingga senyawa aktif yang ada pada daun singkong dapat terekstrak dengan lebih baik pada pelarut etanol dan menghasilkan aktivitas antioksidan tertinggi. Hal ini juga dibuktikan dari penelitian Kemit (2016) yang menyatakan bahwa pelarut etanol menghasilkan nilai aktivitas antioksidan tertinggi pada ekstrak daun alpukat dibandingkan aseton, air, dan metanol.

Hasil persentase aktivitas antioksidan ekstrak daun singkong pada penelitian ini menunjukkan hasil yang sejalan dengan total flavonoid yang menghasilkan nilai tertinggi pada pelarut etanol 90\%. Verdiana (2018) melaporkan bahwa aktivitas antioksidan dapat dipengaruhi oleh jumlah senyawa flavonoid yang ada pada ekstrak daun singkong, semakin banyak senyawa flavonoid maka persentase aktivitas antioksidan akan semakin meningkat.

Pada penelitian ini, total klorofil dan total flavonoid memiliki korelasi positif terhadap aktivitas antioksidan. Grafik korelasi antara total flavonoid dan total klorofil dengan aktivitas antioksidan dapat dilihat pada Gambar 7 dan 8.

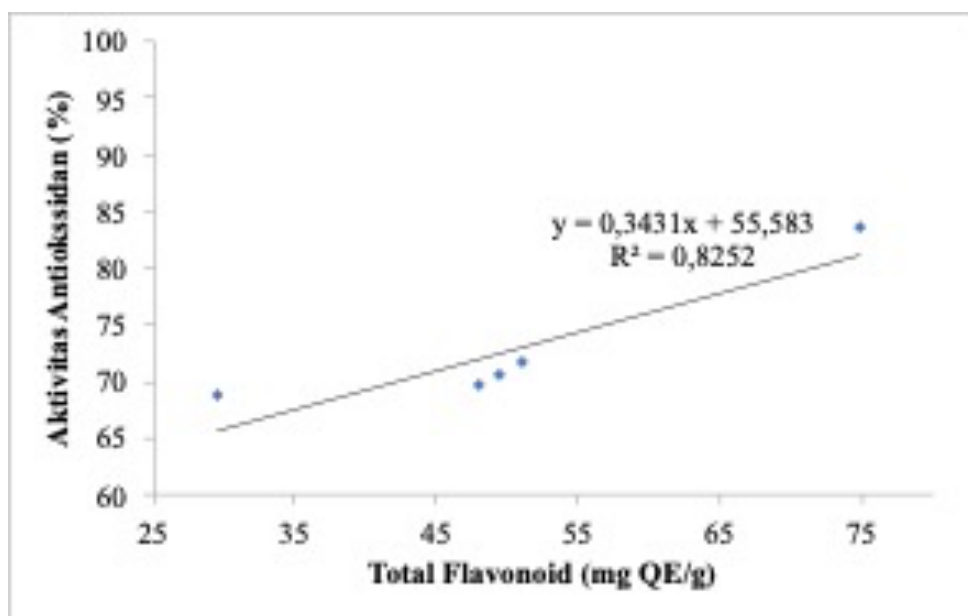

Gambar 7. Grafik korelasi total flavonoid dan aktivitas antioksidan ekstrak daun singkong

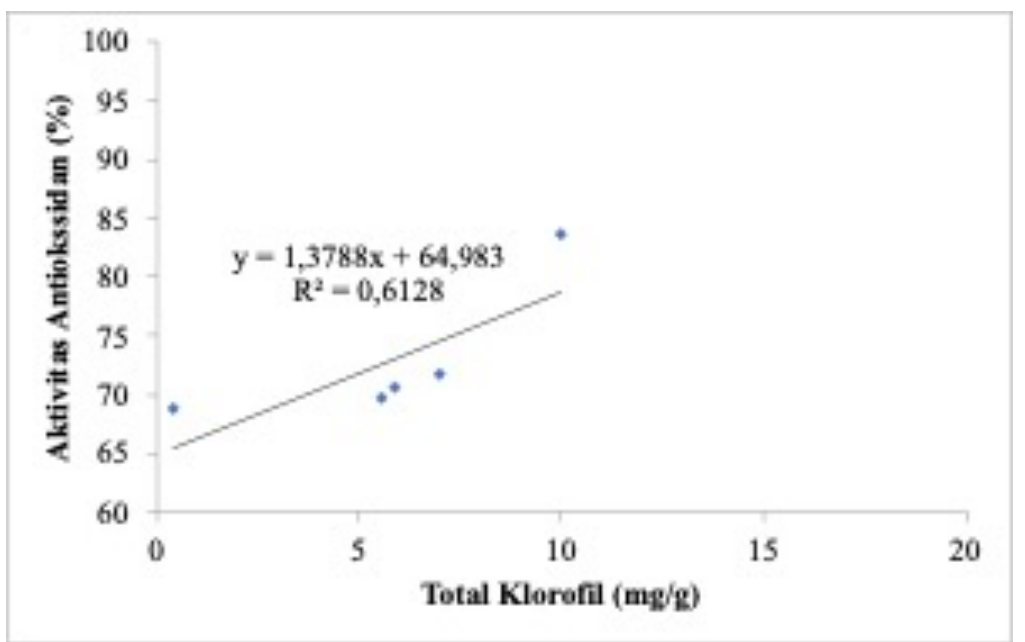

Gambar 8. Grafik korelasi total klorofil dan aktivitas antioksidan ekstrak daun singkong 
Koefisien relasi $\left(\mathrm{R}^{2}\right)$ antara total flavonoid dan aktivitas antioksidan ekstrak daun singkong sebesar 0,8252 yang berarti sebanyak $82,52 \%$ aktivitas antioksidan dipengaruhi oleh flavonoid dan $17,48 \%$ dipngaruhi oleh senyawa lain. Nilai koefisien korelasi yang dihasilkan antara flavonoid dan aktivitas antioksidan menunjukkan korelasi kuat. Koefisien relasi $\left(\mathrm{R}^{2}\right)$ antara total klorofil dan aktivitas antioksidan ekstrak daun singkong sebesar 0,6128 yang berarti sebesar $61,28 \%$ aktivitas antioksidan dipengaruhi oleh klorofil dan $38,72 \%$ dipengaruhi oleh senyawa lain. Nilai koefisien korelasi yang dihasilkan antara klorofil dan aktivitas antioksidan menunjukkan korelasi sedang. Hanief dan Wasis (2017) melaporkan bahwa koefisien korelasi $\left(\mathrm{R}^{2}\right)$ yang memiliki nilai 0,50-0,70 termasuk korelasi sedang dan nilai 0,700,90 termasuk korelasi kuat.

Berdasarkan hasil penelitian, pelarut etanol mampu memberikan hasil persentase aktivitas antioksidan tertinggi yang memiliki nilai $\mathrm{IC}_{50}$ sebesar 917,56 ppm. Hal ini berarti ekstrak daun singkong dengan pelarut etanol mampu menghambat radikal bebas sebesar 50\% dengan konsentrasi 917,56 ppm. Molyneux (2004) melaporkan bahwa suatu senyawa digolongkan sebagai antioksidan sangat kuat jika nilai $\mathrm{IC}_{50}$ kurang dari 50 ppm, kuat jika nilai $\mathrm{IC}_{50}$ antara 50100 ppm, sedang jika nilai IC $_{50}$ berkisar 100-150 ppm, dan lemah jika nilai IC $_{50}$ berkisar 150-200 ppm, dan sangat lemah jika lebih dari 200 ppm. Nilai $\mathrm{IC}_{50}$ ekstrak daun singkong dengan metode MAE pada penelitian ini lebih rendah dibandingkan nilai $\mathrm{IC}_{50}$ ekstrak daun singkong metode maserasi yang dilaporkan oleh Puspitarini (2010) yaitu sebesar 4617,0 ppm sehingga dapat dikatakan bahwa $\mathrm{IC}_{50}$ ekstrak daun singkong dengan metode MAE lebih aktif sebagai antioksidan dibandingkan metode maserasi.

\section{Pengukuran Warna Ekstrak Daun Singkong}

\section{Tingkat Kecerahan $\left(L^{*}\right)$}

Hasil sidik ragam menunjukkan bahwa jenis pelarut berpengaruh sangat nyata $(P<0,01)$ terhadap nilai $L^{*}$ (kecerahan) ekstrak daun singkong. Hubungan jenis pelarut terhadap nilai L* (kecerahan) dapat dilihat pada Tabel 1. Nilai ratarata $L^{*}$ ekstrak daun singkong dalam penelitian ini berkisar antara $26,83-62,00$.

Tabel 1. Rata-rata nilai $L$ * (kecerahan) ekstrak daun singkong

\begin{tabular}{cc}
\hline Perlakuan & Rata-rata Nilai L* (kecerahan) \\
\hline Aquades & $62,00 \pm 0,87 \mathrm{a}$ \\
Metanol 90\% & $37,10 \pm 0,35 \mathrm{c}$ \\
Etanol 90\% & $44,83 \pm 1,17 \mathrm{~b}$ \\
Aseton $90 \%$ & $32,07 \pm 0,86 \mathrm{~d}$ \\
Etil Asetat 90\% & $26,83 \pm 0,70 \mathrm{e}$ \\
\hline
\end{tabular}

Keterangan: Notasi yang sama menunjukkan perlakuan tidak berbeda nyata $(\mathrm{P}>0,05)$

Berdasarkan Tabel 1 dapat dilihat bahwa tingkat kecerahan $\left(\mathrm{L}^{*}\right)$ ekstrak daun singkong tertinggi terdapat pada pelarut aquades yaitu sebesar 62,00 dan tingkat kecerahan terendah terdapat pada pelarut etil asetat $90 \%$ yaitu sebesar 26,83. Jika dilihat dari sistem warna Hunter, notasi 
L*: 0 menunjukkan warna hitam dan 100 menunjukkan warna putih. Tingkat kecerahan $\left(\mathrm{L}^{*}\right)$ ekstrak daun singkong yang tinggi pada aquades berkaitan dengan senyawa aktif yang terekstrak. Pelarut etil asetat memiliki tingkat kecerahan terendah kemungkinan disebabkan karena terjadinya oksidasi sehingga walaupun senyawa aktif yang terkesktrak lebih sedikit dibandingkan etanol, tingkat kecerahannya akan lebih rendah. Hal ini didukung oleh pernyataan Boy et al. (2016) bahwa selama penyimpanan, pigmen akan bersinggungan dengan udara sekitar termasuk oksigen yang menyebabkan warna pigmen berubah. Oleh karena itu, hal tersebut membuat pelarut etil asetat memperoleh nilai $\mathrm{L}^{*}$ (kecerahan) terendah.

\section{Tingkat Kehijauan (a*)}

Hasil sidik ragam menunjukkan bahwa jenis pelarut berpengaruh sangat nyata $(\mathrm{P}<0,01)$ terhadap nilai $a^{*}$ (hijau-merah) ekstrak daun singkong. Hubungan jenis pelarut terhadap nilai a* dapat dilihat pada Tabel 2. Nilai rata-rata $a^{*}$ ekstrak daun singkong dalam penelitian ini berkisar antara -2,17 sampai - 9,97.

Nilai a* menyatakan tingkat warna hijau sampai merah dengan notasi a*: 0 sampai +80 menunjukkan warna merah dan nilai 0 sampai -80 menunjukkan warna hijau. Hal ini sudah sesuai dengan hasil penelitian yang memperoleh nilai a negatif. Semakin tinggi nilai minus maka warna yang dihasilkan akan lebih hijau dibandingkan nilai minus yang lebih rendah. Hasil penelitian menunjukkan bahwa nilai $a^{*}$ ekstrak daun singkong pada pelarut etanol memberikan warna yang lebih hijau dibandingkan pelarut aquades. Hal ini akibat dari hasil ekstraksi yang mana hasil ekstraksi pelarut etanol memperlihatkan warna yang lebih hijau dibandingkan pelarut aquades sehingga nilai a* pada pelarut etanol memberikan nilai a* tertinggi. Warna hijau disebabkan oleh kandungan klorofil pada ekstrak daun singkong yang mana pada hasil total klorofil didapatkan pelarut etanol mampu menghasilkan nilai total klorofil yang tinggi dibandingkan pelarut aquades sehingga hal tersebut mempengaruhi nilai a* dari ekstrak daun singkong.

\section{Tingkat Kekuningan (b*)}

Hasil sidik ragam menunjukkan bahwa jenis pelarut berpengaruh sangat nyata $(\mathrm{P}<0,01)$ terhadap nilai $b^{*}$ (kuning-biru) ekstrak daun singkong. Hubungan jenis pelarut terhadap nilai $b^{*}$ dapat dilihat pada Tabel 3. Nilai rata-rata $b^{*}$ ekstrak daun singkong dalam penelitian ini berkisar antara $12,23-48,30$.

Tabel 2. Rata-rata nilai a* (hijau-merah) ekstrak daun singkong

\begin{tabular}{cc}
\hline Perlakuan & Rata-rata Nilai a* (Merah-Hijau) \\
\hline Aquades & $-2,17 \pm 0,06 \mathrm{a}$ \\
Metanol $90 \%$ & $-8,77 \pm 0,15 \mathrm{~b}$ \\
Etanol $90 \%$ & $-9,97 \pm 0,21 \mathrm{c}$ \\
Aseton $90 \%$ & $-8,97 \pm 0,06 \mathrm{bc}$ \\
Etil Asetat $90 \%$ & $-7,97 \pm 0,15 \mathrm{~b}$ \\
\hline
\end{tabular}

Keterangan: Notasi yang sama menunjukkan perlakuan tidak berbeda nyata $(\mathrm{P}>0,05)$ 
Tabel 3. Rata-rata nilai $b$ * (kuning-biru) ekstrak daun singkong

\begin{tabular}{cc}
\hline Perlakuan & Rata-rata Nilai b* (Kuning-Biru) \\
\hline Aquades & $48,30 \pm 1,91 \mathrm{a}$ \\
Metanol 90\% & $19,23 \pm 0,40 \mathrm{~b}$ \\
Etanol 90\% & $20,27 \pm 0,76 \mathrm{~b}$ \\
Aseton 90\% & $14,17 \pm 1,01 \mathrm{c}$ \\
Etil Asetat 90\% & $12,23 \pm 0,70 \mathrm{c}$ \\
\hline
\end{tabular}

Keterangan: Notasi yang sama menunjukkan perlakuan tidak berbeda nyata $(\mathrm{P}>0,05)$

Tabel 3 menunjukkan bahwa nilai $\mathrm{b}^{*}$ ekstrak daun singkong tertinggi terdapat pada pelarut aquades sedangkan nilai $b^{*}$ terendah terdapat pada pelarut etil asetat 90\%. Hasil penelitian menunjukkan bahwa nilai $b^{*}$ positif yang mana notasi ini menunjukkan ekstrak daun singkong cenderung berwarna kuning. Hal ini didukung oleh penelitian Atika et al. (2016) yang melaporkan bahwa nilai $b^{*}$ pada pelarut air memiliki nilai lebih baik dibandingkan alkohol pada ekstrak daun gambir. Total klorofil pada ekstrak daun singkong dapat mempengaruhi nilai b*. Berdasarkan nilai total klorofil pada ekstrak daun singkong yang didapat pada penelitian ini, aquades memiliki nilai total klorofil terendah yang berarti aquades memiliki warna yang cenderung kuning kecoklatan bukan hijau sehingga nilai $b^{*}$ yang dihasilkan paling tinggi dibandingkan pelarut jenis lainnya. Ekstrak daun singkong dengan pelarut etanol, metanol, aseton, dan etil asetat memiliki nilai $b^{*}$ yang rendah karena ekstrak cenderung berwarna hijau yang dihasilkan akibat adanya klorofil khusunya jenis klorofil b karena klorofil b menyerap cahaya berwarna biru orange sehingga warna yang dipancarkan menjadi hijau. Klorofil merupakan senyawa yang cukup sensitif terhadap cahaya dan panas sehingga hal tersebut memungkinkan terjadinya degradasi klorofil menjadi feofitin yang berwarna coklat kekuningan (Aryanti, 2016).

\section{KESIMPULAN}

Jenis pelarut berpengaruh pada nilai rendemen, kadar air, total flavonoid, total klorofil, aktivitas antioksidan, dan nilai $\mathrm{L}^{*}, \mathrm{a}^{*}, \mathrm{~b}^{*}$ dari ekstrak daun singkong pada metode Microwave Assisted Extraction (MAE). Jenis pelarut terbaik adalah pelarut etanol $90 \%$ yang menghasilkan karakteristik rendemen sebesar $19,84 \%$, total flavonoid sebesar 74,90 mg QE/g, total klorofil sebesar $9,98 \mathrm{mg} / \mathrm{g}$, aktivitas antioksidan $83,67 \%$, dan nilai $L^{*}$ sebesar 44,83 , a* sebesar $-9,97, b^{*}$ sebesar 20,27.

\section{DAFTAR PUSTAKA}

Ai, N.S dan Y. Banyo. 2011. Konsentrasi klorofil daun sebagai indikator kekurangan air pada tanaman. Jurnal Ilmiah Sains. 11(2):167-173.

Aisy, G.A.R. 2018. Analisa Kandungan Klorofil Ekstrak Daun Pepaya (Carica papaya L.) terhadap Variasi Waktu Ekstraksi dengan Menggunakan Ekstraktor Hidrotermal. Skripsi S1. Tidak dipublikasikan. Departemen Teknologi Industri Univeritas Diponegoro, Semarang.

Anggraini, D., A. Suhada dan S. Rahmawati. 2017. Efektivitas ekstrak etanol daun singkong (Manihot esculenta) dalam mengobati luka bakar kulit punggung tikus (Ratus novergicus) jantan. Jurnal Farmasetis. 6(2):39-46.

Arrohmah. 2007. Studi Karakteristik Klorofil pada Daun Sebagai Material Photodetector Organic. Skripsi S1. Tidak dipublikasikan. Fakultas Matematika dan Ilmu Pengetahuan Alam Universitas Sebelas Maret, Surakarta. 
Aryanti, N., A. Nafiunisa dan F.M. Willis. 2016. Ekstraksi dan karakterisasi klorofil dari daun suji (Pleomele angustifolia) sebagai pewarna pangan alami. Jurnal Aplikasi Teknologi Pangan. 5(4): 129-135.

Atika, V., Farida dan T. Pujilestari. 2016. Kualitas pewarnaan ekstrak gambir pada batik sutera. Balai Besar Kerajinan Batik. 33(1): 25-32.

Azizah, Z., F. Elvis, Zulharmita, S. Misfadhila, B. Chandra dan R.D. Yetti. 2020. Penetapak kadar flavonoid rutin pada daun ubi kayu (Manihot esculenta Crantz.) secara spektrofotometri sinar tampak. Jurnal Farmasi Higea. 12(1): 90-98.

Chang, C.C., M.H. Yang, H.M. Wen and J.C. Chern. 2002. Estimation of total flavonoid content in propolis by two complementary colorimetric methods. Journal of Food and Drug Analysis. 10(3):178-182.

Dewatisari, W.F., L. Rumiyanti dan I. Rakhmawati. 2017. Rendemen dan skrining fitokimia pada ekstrak daun sanseviera sp. Jurnal Penelitian Pertanian Terapan. 17(3):197-202.

Fabrowska, J., B. Messyasz, J. Syzling, J. Walkowiak and B. Leska. 2017. Isolation of chlorophylls and carotenoids form freshwater algae using different extraction methods. Phycological Research. 10:2-6.

Firdiyani, F., T.W. Agustini dan W.F. Ma'ruf. 2015. Ekstraksi senyawa bioaktif sebagai antioksidan alami Spirulina plantesis segar dengan pelarut yang berbeda. JPHPI. 18(1):28-37.

Hanief, Y.N dan W. Himawanto. 2017. Statistik Pendidikan. Deepublish (Grup Penerbitan CV Budi Utama), Yogyakarta.

Harborne, J.B. 1996. Metode Fitokimia: Cara Menganalisis Tanaman. Edisi Ke 2. Penerjemah K. Padmawinata. Institut Teknologi Bandung, Bandung.

Jain, T., V. Jain, R. Pandey, A. Vyas and S.S. Shukla. 2009. Microwave assisted extraction for phytoconstituents - an overview. Asian Journal Research Chemistry. 1(2):19-25.

Kemit, N., I.W.R. Widarta dan K.A.Nocianitri. 2016. Pengaruh Jenis Pelarut dan Waktu Ekstraksi terhadap Kandungan Senyawa Fllavonoid dan Aktivitas Antioksidan Ekstrak Daun Alpukat (Persea americana Mill.). Skripsi S1. Tidak dipublikasikan. Fakultas Teknologi Pertanian Universitas Udayana, Bali.

Khan, R.A., M.R. Khan, S. Sahreen and M. Ahmed. 2012. Evaluation of phenolic contents and antioxidant activity of various solvent extracts of Sonchus asper (L) Hill. Chemistry Central Journal. 6(12):1-7.

Khotimah, H., E.W. Anggraeni dan A. Setianingsih. Karakterisasi hasil pengolahan air menggunakan alat destilasi. Jurnal Chemurgy. 1(2):34-38.
Maligan, J.M., A.P. Marditia dan W.D.R. Putri. 2015. Analisis senyawa bioaktif ekstrak mikroalga laut (Tetraselmis chuii) sebagai sumber antioksidan alami. Jurnal Rekapangan. 9(2):1-10.

Novitasari, A.E dan R. Adawiyah. 2018. Perbandingan pelarut pada ekstraksi total klorofil daun mangkokan dengan metode spektrofotometri. Jurnal Sains. 8(15):16-20.

Puspitarini, B.A. 2010. Uji Aktivitas Antioksidan Ekstrak Daun Singkong (Manihot Folium) Menggunakan Metode Diphenylpicryl Hydrazyl (DPPH). Skripsi S1. Tidak dipublikasikan. Fakultas Farmasi Universitas Sanata Dharma, Yogyakarta.

Putranto, A.W., S.R. Dewi, N. Izza, D.R. Yuneri, M.Y.S. Dachi dan S.H. Sumarlan. 2018. Ekstraksi senyawa fenolik daun kenikir (Cosmos caudatus) menggunakan Microwave Assisted Extraction (MAE). Jurnal Rona Teknik Pertanian. 11(1):60-70.

Putri, W.D.R., E. Zubaidah dan N. Sholahudin. 2012. Ekstraksi pewarna alami daun suji, kajian pengaruh blanching dan jenis bahan pengekstrak. Jurnal Teknologi Pertanian. 4(1):13-24.

Ridlo, A., R. Pramesti, Koesoemadji, E. Supriyanthini dan N. Soenardjo. 2017. Aktivitas antioksidan ekstrak daun mangrove Rhizopora mucronata. Buletin Oseanografi Marina. 6(2): 110-116.

Rifai, G., I.W.R. Widarta dan K.A. Nocianitri. 2018. Pengaruh jenis pelarut dan rasio bahan dengan pelarut terhadap kandungan senyawa fenolik dan aktivitas antioksidan ekstrak biji alpukat (Persea americana Mill.). Jurnal ITEPA. 7(2):22-32.

Rohimat, I. Widowati dan A. Trianto. 2014. Aktivitas antioksidan ekstrak metanol rumput laut coklat (Turbinaria conoides dan sargassum cristaefolium) yang dikoleksi dari pantai rancabuaya garut jawa barat. Journal of Marine Research. 3(3):304-313.

Sari, E.R dan Meitisa. 2017. Standarisasi mutu ekstrak daun singkong. Jurnal Ilmiah Bakti Farmasi. 2(1):13-20.

Sekali, E.E.K., N.M. Wartini dan L. Suhendra. 2020. Karakteristik ekstrak aseton pewarna alami daun singkong (Manihot Esculenta C.) pada perlakuan ukuran partikel bahan dan lama maserasi. Jurnal Ilmiah Teknologi Pertanian AGROTECHNO. 5(2):1-11.

Setiari, N dan Y. Nurchayati. 2009. Eksplorasi kandungan klorofil pada beberapa sayuran hijau sebagai alternatif bahan dasar food suplement. BIOMA. (11(1):6-10.

Sinaga, A.S. 2019. Segmentasi ruang warna L*a*b*. Jurnal Mantik Penusa. 3(1):43-46. 
Sulistyo, S. 2019. Pengaruh Jenis Pelarut dan Konsentrasi pelarut terhadap Rendemen Ekstrak Flavonoid Daun Sawo Duren (Crysophillum cainito L.) dengan Metode Maserasi. Skripsi S1. Tidak dipublikasikan. Fakultas Teknik UMS, Surakarta.

Verdiana, M., I.W.R. Widarta dan I.D.G.M. Permana. 2018. Pengaruh jensi pelarut pada ekstraksi menggunakan gelombang ultrasonik terhadap aktivitas antioksidan ekstrak kulit buah lemon (Citrus limon (Linn.) Burm F.). Jurnal Ilmu dan Teknologi Pangan. 7(4): 213-222.

Yasa, G. T., N.K. Putra dan A.A.S. Wiadnyani. 2019. Pengaruh konsentrasi etanol terhadap aktivitas antioksidan ekstrak daun sirih merah (Piper crocatum Ruitz \& Pav) menggunakan metode Microwave Assisted Extraction (MAE). Jurnal Ilmu dan Teknologi Pangan. 8(3):278-284. 